\section{Schedule control of concurrent fixed-ratio responding and discrimination acquisition in chickens}

SHELDON B. SPARBER, Department of Pharmacology, University of Minnesota, Minneapolis, Minn. 55455

Starting at 1 week of age, domestic chicks were shaped to work on a concurrent FR-FR (houselight-food) schedule of reinforcement. When a discrimination was superimposed upon the concurrent schedule, patterns of responding indicated a chaining effect. The houselight appeared to be necessary for eating behavior and did not have much social reinforcing properties of its own. This was supported by a severe decrease in responding on the houselight key when the food key was unavailable. Activating a low-intensity lamp near the feeder also resulted in much diminished responding on the houselight key.

Recently, Marley \& Morse (1966) showed the rapid acquisition of multiple fixed-ratio (FR), fixed-interval performance by newly hatched chicks. The advantage of a mirror in the box during the shaping procedure, as well as their data showing a reciprocal relation between key pecking and distress chirping, supports the concept that social reinforcement plays a significant role in the life of the young chicken. Adult fighting cocks have also been shown to work for the availability of a mirror, presumably allowing display of agonistic behavior toward "another" male (Thompson, 1964). Thompson's three-component concurrent (food, water, light-mirror) schedule resulted in strained ratio performance, indicating that food had greater reinforcing properties than did

Fig. 1. Cumulative records of concurrent FR-FR responding for houselight and food by a 2-week-old chick. Feeding was difficult or impossible in the darkened chamber, resulting in continuing runs on the food key even during hopper activation (a, excursion of response pen during reinforcement slash). Event pens were deflected downward during the 15-sec interval when the houselight was on. This record shows acquisition of coordinated behavior resulting in facilitation of eating (b). The record on the right shows the response output ratio equal to unity. It is generated after exposing the bird to schedules that punish greater response rates (see Results and Discussion). water, which, in turn, was greater than the light-mirror combination. The following experiments were performed in order to determine if immature nonfighting male or fernale chickens would key peck for an opportunity to view themselves in a mirror and to study further the performance capability of this species with a more complex paradigm.

\section{METHOD}

The Ss were five $f_{1}$ generation Columbian Rock X New Hampshire Red chickens (three males, two females), hatched and reared in our laboratories. They were started in the operant conditioning chamber when approximately 1 week of age. Training took place in a two-key operant conditioning chamber fabricated from an aluminum picnic chest. It was equipped with a modified Garbrands food hopper so that the Ss could eat from a $1 / 2$-in. hole cut in the 1/4-in. hardware-cloth floor. In addition to the keys, the panel contained a two-way glass mirror, transilluminated by a $6-\mathrm{W}$ candelabra-type light, which rendered it ineffectual as a mirror when the more brilliant houselight, mounted at the top front of the panel, was off. A Dialco (28 V, 0.04 A) light of low intensity, positioned at the feeding hole, completed the manipulandum panel. Schedules of reinforcement and data collection were automatically programmed and controlled by relay-type equipment in an adjacent room.

Training of the young chicks was essentially identical to that described by Marley \& Morse (1966), except that the available key was transilluminated with a green light, and they were trained to key peck for food in the presence of a clicking tone (light and tone to be used as discriminative stimuli later in the experiment). Since the houselight was on during the training procedure, the second key (later to be used to turn the houselight on) was unavailable. In all instances, the food hopper was available for $3 \mathrm{sec}$ when activated.

The schedule of reinforcement for food went from a single FR-1 during training to as high as FR-60 and FR-75. After stabilization at higher ratios, the second key in the chamber was uncovered and the houselight turned off. At this point, the chamber was unilluminated, except for some stray light coming from behind the two-way mirror (now transparent to the bird). As with the food, the ratio requirement for the houselight was initially low but was brought up to FR-45 and higher quite rapidly. Upon satisfaction of the ratio requirements, the houselight went on and stayed on for predetermined intervals, which depended upon the experimental manipulation in progress at the time. Since both the food key and the houselight key were available at the same time, the schedule was, operationally, a concurrent FR-FR.

\section{RESULTS AND DISCUSSION}

Figure 1 shows sample cumulative records of the development of concurrent light-food responding after fixed-ratio performance for food had been stabilized (Ss were approximately 3 weeks old). In this case, the houselight was on for $15 \mathrm{sec}$, a period long enough to allow the FR-15 for food to be satisfied and for $3 \mathrm{sec}$ of feeding to occur. Although the birds learned to turn the houselight on rather rapidly, they persevered on the food key for extended bursts, even when the food hopper was activated (Fig. 1a). Once they had learned to coordinate their light and food responding (Fig. 1b), they continued to work for extended periods of time (hours) on whatever ratio combinations

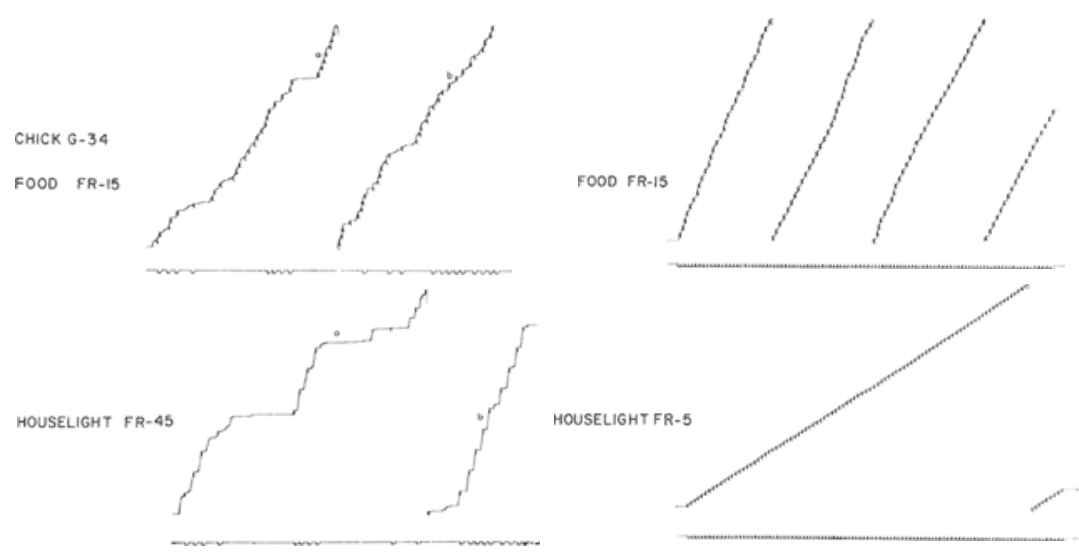




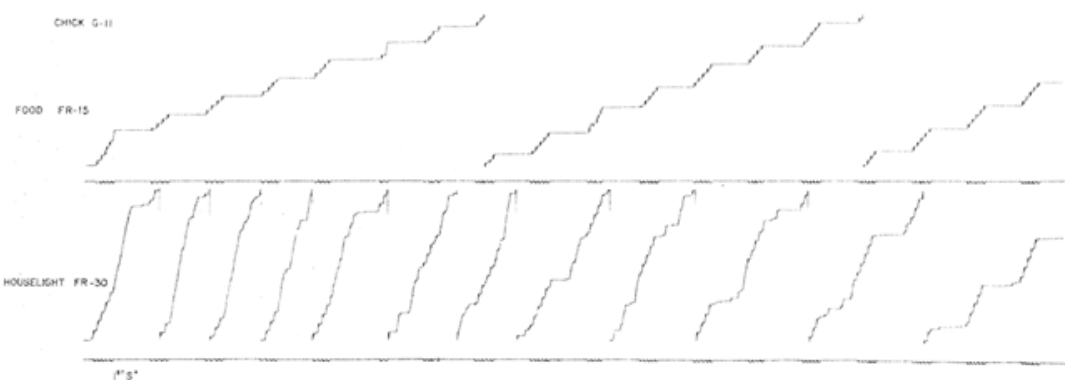

were presented to them, provided satiation did not occur. If ratio requirements for food remained fairly low (approximately FR-15), they satisfied the requirements, took the food, and, during the remainder of the $15-\mathrm{sec}$ period that the houselight was on, continued to work for food. If there was enough time for another run on the food key but not enough time to eat the food once the hopper was activated (houselight off when hopper was activated), the second run was apparently punished, and the birds spaced their responding so that the number of food reinforcements taken equalled the number of times the houselight was turned on (Fig. 1). During the remainder of the period chickens displayed intervening behavior (preening, pecking at spots on the walls of the box, etc.).

When a discrimination was introduced (keys transilluminated with a red light instead of green and tone off), the birds initially continued to work upon the houselight key at high rates (postextinction bursts). As long as they could not turn on the light, which presumably enabled them to see and eat the food, their key pecking on the food key was literally zero (food-key responding was also inconsequential). During the $3-\mathrm{min}$ time-in (SD), the number of light "reinforcements" remained equal to the number of food reinforcements. Figure 2 shows the development of the discrimination over a $2 \frac{1}{2}-h$ period. To determine if the role of the houselight was part of a stimulus complex (light-mirror) with reinforcing properties or a component in a chain leading to facilitation of feeding (food reinforcement), the food key was

Fig. 3. Unavailability of the food key resulted in sustained pecking on the light key only during the first $\mathrm{S}^{\mathrm{D}} \cdot \mathrm{S} \Delta$ cycle (a, event pen on lower record was depressed during $3-\min S^{D}$ ). When the food key was again available (b) and the feeder light functioning during its operation, responding on the houselight key rapidly diminished, indicating little, if any, reinforcing properties of the houselight in these experiments.
Fig. 2. Cumulative records showing the development of a discrimination superimposed upon a concurrent FR-FR (food-light) schedule of reinforcement. Availability of the houselight and food occurred during the 3-min $S^{D}$, and responding on both keys remained coordinated. Until the discrimination was learned (6-min $s \Delta$ ), there was sustained responding on the houselight key and complete absence of responding on the food key. Event pens were deflected downward during the 15 -sec interval when covered, leaving the houselight key available for responding. The rate of responding for the houselight was initially high during the first $3-\mathrm{min} S \mathrm{~S}$. behavior resulting from such contingencies Discriminative control was maintained; in is often a product of interaction of its most cases, the birds ceased responding separate components (Catania, 1966). The during the $S \Delta$ (Fig. 3a). During the strong interaction of the light-food subsequent one or two SD-S $\Delta$ cycles, components in these experiments is most responding on the houselight key rapidly obvious when a discrimination is diminished, showing it to have little, if any introduced. With all five Ss, responding on reinforcing power in this schedule. In the food key was absent if a terminal addition, loss of activity on the houselight response on the light key, resulting in key resulted when the small Dialco light illumination, could not be made (i.e., $S \Delta$ ). was illuminated near the feeder after the food key was reinstated (Fig. 3b).

Although Thompson's (1964) chickens were housed in the experimental chamber, thereby increasing the probability of responding leading to visual reinforcement (mirror), their general predisposition toward agonistic-display behavior (fighting) perhaps accounted for their responding on the light key for access to the mirror. On several occasions, the $S s$ in the present study were left in the experimental chamber for extended periods of time. During these periods $(24-72 \mathrm{~h})$, they continually turned the houselight on only when it was followed by key-pecking for food. When food satiation occurred, there was complete cessation of key-pecking for the houselight. In the absence of a mirror, training proceeded normally and distress cheeping was minimal in chicks older than 5 days of age (Marley \& Morse, 1966). It is possible that the importance of social (visual) reinforcement diminishes as nonfighting birds age. This seems to be supported by the experiments reported herein. Although concurrent schedules, by definition, are formally independent,
The data reported in this paper were collected over a relatively short period (1-2 months). The five $\mathrm{Ss}$ in this study were later used, along with several others, in a study of drug effects upon this behavior. The general response pattern did not change appreciably; if anything, the discrimination became more precise. The ratio of food reinforcements to light onsets always approximated unity when programmed to generate that performance. Animals continued to turn the houselight on only in conjunction with food

CATANIA, A. C. Concurrent operants. In W. K. Honig (Ed.), Operant behavior: Areas of research and application. New York: Appleton-Century-Crofts, 1966.

MARLEY, E., \& MORSE, W. H. Operant conditioning in the newly hatched chicken. Journal of the Experimental Analysis of Behavior, 1966, 9, 95-103.

THOMPSON, T. I. Visual reinforcement in fighting cocks. Journal of the Experitnental Analysis of Behavior, 1964, 7, 45-49.

\section{NOTE}

1. This research was supported by National Institutes of Mental Health Training Grant No. MH-8565. procurement.

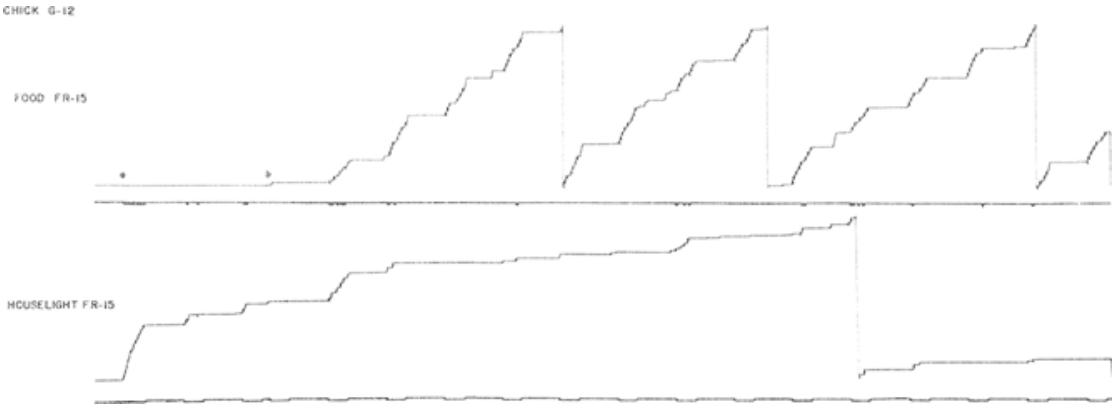

